\title{
REIMAGINANDO A HERANÇA AFRICANA EM CONTOS
}

\author{
Felipe Fanuel Xavier Rodrigues \\ (Fundação Técnico-Educacional Souza Marques) \\ https://orcid.org/0000-0002-5653-6846
}

\section{RESUMO}

O objetivo deste artigo é apresentar um estudo crítico de contos selecionados de Mãe Beata de Yemonjá (1931-2017), autora de Histórias que a minha avó contava (2004) e Caroço de Dendê (2008). Em sua obra, a escritora empreende representações literárias de elementos simbólicos derivados de culturas africanas da forma como foram reconfiguradas no Brasil, enquanto território diaspórico de sujeitos negros. Os tropos dessa África reimaginada e recriada desvelam a agência cultural de uma narradora que lida com a cultura como estratégia de sobrevivência em contextos marcados por uma história de racismo e intolerância em relação às tradições de matriz africana.

PALAVRAS-CHAVE: herança africana reimaginada; contos afro-brasileiros; Mãe Beata de Yemonjá.

\section{REIMAGINING THE AFRICAN HERITAGE IN SHORT STORIES}

\section{ABSTRACT}

This article aims to present a critical study of selected short stories by Mãe Beata de Yemonjá (1931-2017), author of Histórias que a minha avó contava (2004) and Caroço de Dendê (2008). In her work, the writer engages in literary representations of symbolic elements derived from African cultures and reconfigured in Brazil, understood as a diasporic territory for black subjects. The tropes of this reimagined and recreated Africa unveil the cultural agency of a storyteller who deals with culture as a strategy of survival in 
contexts marked by a history of racism and intolerance towards African-derived traditions.

KEYWORDS: reimagined African heritage; Afro-Brazilian short stories; Mãe Beata de Yemonjá.

Este artigo apresenta um estudo crítico de contos selecionados de Mãe Beata de Yemonjá (1931-2017), autora de Histórias que a minha avó contava (2004) e Caroço de Dendê (2008). Em sua obra, a escritora empreende representações literárias de elementos simbólicos derivados de culturas africanas da forma como foram reconfiguradas no Brasil, enquanto território diaspórico de sujeitos negros. Os tropos dessa África reimaginada e recriada desvelam a agência cultural de uma narradora que lida com a cultura como estratégia de sobrevivência em contextos marcados por uma história de racismo e intolerância em relação às tradições de matriz africana.

Nascida no Recôncavo Baiano e falecida no Recôncavo da Guanabara (hoje Baixada Fluminense), Beatriz Moreira Costa construiu uma impressionante trajetória de vida até se tornar a escritora Mãe Beata de Yemonjá, muito respeitada como ialorixá, ativista e palestrante em diversos eventos acadêmicos e culturais no Brasil e no exterior. A alcunha por meio da qual ela seria conhecida na sociedade provém de suas vivências como mulher negra e sacerdotisa do candomblé, a religião afro-brasileira que narra a história da África em solo brasileiro. Motivada por um compromisso de divulgar a sabedoria dos terreiros, sua produção literária materializa em contos uma residual episteme africana que perdura na tradição oral retraduzida em performance de mitos, divinação, rituais, música, dança e transe de origem iorubá. Além da relação religiosa com essa tradição africana, a autora também possui laços familiares com a terra iorubá, conforme Haroldo Costa (2010, p. 19), que localiza as raízes ancestrais de Mãe Beata de Yemonjá no povo tapa (ou nupe), que viveu sob a influência dos iorubás e igbos.

Segundo Robert Farris Thompson (1984, p. 4), entre as civilizações tradicionais da África negra, os iorubás se destacam por seu urbanismo e força artística. Na cidade sagrada de Ilê-Ifé, as mãos dos escultores iorubás modelavam "arte esplêndida" entre os séculos X e XII, "quando nada 
de qualidade parecida estava sendo produzida na Europa". Caracterizada por cidades-estados autossuficientes, ricas em arte e poesia, a terra iorubá deu à luz um povo com uma visão de mundo estética. Como afirma Thompson (1984, p. 5), "os iorubás avaliam tudo esteticamente - do sabor e cor de um inhame às qualidades de um corante, ao vestuário e postura de uma mulher ou um homem". Apreciadores do frescor e improvisação nas artes, os iorubás veem a beleza no meio, não em extremos. Essa cosmovisão iorubá se manifesta nas artes com tropos religiosos, incluindo textos literários que representam elementos dessa tradição recriada na diáspora.

Henry Louis Gates (1989, p. 5) observa que os negros escravizados utilizaram a memória para recriar um sistema africano de significado e crença "preservado pela tradição oral, improvisado em ritual - sobretudo nos rituais de narrativa oral repetida - e legado às gerações subsequentes". Entre as figuras que mais aparecem nas tradições narrativas negras está o trickster divino Exu. Em diálogo com Wole Soyinka, Gates propõe a expressão Esu- 'tufunaalo ${ }^{1}$ para pensar os princípios metodológicos de interpretação de textos negros.

Ao estabelecer os fundamentos de uma crítica literária de autores de origem africana, Gates $(1989$, p. 7) sugere a revisão do termo "hermenêutica", ditado pela história mitológica da divindade grega Hermes; bem como a retradução de "logos" pelo termo iorubá ase (ou axé), que denota "a palavra com irrevogabilidade, reforçada com dupla garantia e autenticidade intrépida". Dessa forma, a palavra grafada por mãos negras afirma-se como geratriz de novos discursos, entrelaçando ancestralidade, tradições e vivências. Posicionado em encruzilhadas discursivas nas quais línguas, culturas e tradições se encontram, o crítico desses textos atua como um "trickster do discurso" (GATES, 1989, p. 65).

Discursos possuem raízes em histórias individuais e coletivas. A escrita de mulheres afro-brasileiras pode ser considerada um fenômeno improvável, dada a posição inferior que a maioria delas historicamente ocupa na sociedade. Essa evidência de racismo estrutural no Brasil é combatida com palavras que reconhecem o lugar de fala do enunciador: "Sou mulher negra. Sou forte./ Sou lutadora. Sou guerreira" (citado por COSTA, 2010, p. 149). Nesses versos, Mãe Beata afirma sua negritude ao mesmo tempo em que desloca suas forças criativas para uma luta pela sobrevivência em um ambiente de discriminação racial. Seu trabalho se

1 Literalmente, "aquele que desata os nós de Exu". 
junta ao conjunto de obras de escritoras negras que dão passos de continuidade ao "redespertar político e cultural negro" no país, cujo impulso foi prefigurado pela obra de Carolina Maria de Jesus (MCLAUGHLIN, 1990 , p. xxxvi). Seguindo uma tradição de protesto social que remonta à obra de Maria Firmina dos Reis (1825-1927), as escritoras afro-brasileiras contemporâneas lançam mão da palavra escrita para articular "vozes outrora silenciadas e marginalizadas, demandando respeito e dignidade, bem como liberdade para ser quem são sem se desculparem ou serem tratadas com indulgência" (AFOLABI, 2009, p. 80).

A escrita afrodescendente encontra sua liberdade no que Edward Said (1995, p. 13) denomina "poder de narrar", tão empregado para a manutenção do imperialismo, mas agora assumido como arma por sujeitos historicamente deixados à margem. Para Conceição Evaristo (2010, p. 139), a imagem do "quilombo" contribui para uma reflexão sobre o lugar da literatura negra brasileira. Trata-se de um "espaço de vivência marcado pelo enfrentamento, pela audácia de contradizer, pelo risco de contradizer o sistema". Como espaço de luta pela liberdade, o quilombo era uma escolha da pessoa escravizada em fuga. Quando vozes negras buscam falar por si, elas enfrentam as mais variadas formas de essencialismo, estereótipos e construções sociais que objetificam a subjetividade de origem africana. Assim, a partir de uma posição de marginalidade, a identidade negra reivindica sua centralidade com base em uma revisão das narrativas sobre suas heranças ancestrais.

Como escritora da história de uma África recontada, Mãe Beata de Yemonjá reinventa a própria identidade, superando a condenação ao espaço de mera vítima das brutalidades da escravização e do colonialismo. Achille Mbembe (2017, p. 297) defende a necessidade da autoinvenção africana ao afirmar que "a verdadeira política de identidade consiste em incessantemente alimentar, atualizar e reatualizar as suas capacidades de autoinvenção". Ao recontar tradições africanas herdadas, a escritora afro-brasileira recria as imagens da África no Brasil, substituindo a história de morte e destruição pela recriação de signos de vidas que se renovam.

\section{Histórias de uma africanidade recontada}

Em sua obra Histórias que a minha avó contava (2004), Mãe Beata apresenta narrativas que contribuíram para a sua própria formação. De sua avó Josefa ela herdou um saber ancestral derivado, em grande parte, da bisavó de origem tapa, grupo étnico localizado ao norte da 
atual Nigéria, sob a influência dos iorubás. Através de uma experiência pessoal, a autora relata como ocorreu a preservação e a transmissão desse legado matriarcal de tradições:

Minha avó guardava uma espécie de mala que continha, lá no fundo, pedaços de ferro, algumas pedras, uma corrente comprida, um crucifixo, búzios e corais. Foi herança da mãe dela. Não era permitido que a gente abrisse ou mexesse na tal mala. Nós, crianças, passávamos longe dela, mas numa manhã me levantei mais cedo e vi vó Josefa fazendo um ritual diante da mala aberta. Ela veio com uma quartinha de água do rio, derramou um pouco no pé da mesa onde a mala estava aberta. Depois pingou um pouco na cabeça e colocou a quartinha no chão, enquanto entoava baixinho alguma coisa que eu não conseguia entender. Eu espiava tudo escondida, mas quando ela se dirigiu para a porta dei uma corrida e pude ver o interior da mala (citado por COSTA, 2010, p. 42).

Quando foram violentamente removidos da África e escravizados nas Américas, homens e mulheres de origem africana dispunham de recursos limitados para preservação de sua cultura. A imagem de uma mala que contém os itens mais importantes para um ritual feito por uma senhora negra é simbólica. A mala representa tanto aquilo que de mais precioso ela guarda como sua jornada da terra natal para o Novo Mundo ou a iminente partida deste mundo para o outro. Ferro e pedras podem fazer referência a dois poderosos orixás respectivamente: Ogum, o senhor do ferro e da guerra; e Xangô, o deus do trovão e protetor da justiça, que pode ser encontrado em uma pedreira. A presença de uma corrente mantém a memória da servidão que foi imposta ao seu povo. O crucifixo corresponde tanto ao símbolo da religião institucional do opressor branco como à encruzilhada, que é o espaço regido por Exu, a divindade de todas as direções. Conchas e corais evocam a prática divinatória, geralmente realizada através de búzios no Brasil. Assim, a representação desses objetos é feita em fragmentos e os objetos sagrados se tornam emblemas de tradições religiosas que são inferidas a partir do texto lido como um palimpsesto.

As crianças da família de dona Josefa não eram autorizadas a terem acesso à mala, mas a pequena Beatriz teria uma epifania que marcaria sua história. A performance de sua avó Josefa diante da mala aberta lhe permitiu a leitura das primeiras linhas de uma rica tradição ritualística que seria significativa para sua experiência de vida: 
Na hora eu não percebi, mas aquela mala e o seu conteúdo abriram os caminhos da minha espiritualidade, que já era latente. Quem é de santo, quer dizer, quem nasceu para o culto dos orixás, desde seu primeiro sopro de vida traz o sinal de que essa será a sua missão (citado por COSTA, 2010, p. 42).

Os olhos de uma criança puderam ver imagens da avó Josefa derramando água ao pé da mesa e em sua própria cabeça. Provavelmente, tratava-se de um ritual para Iemanjá, proprietária das águas, ou Oxum, divindade das águas doces. O som dos cânticos que Beata não conseguiu compreender poderia ter sido ouvido em iorubá, a língua ritual que preserva o vínculo com a África. Além disso, os elementos dentro da mala podem ser interpretados como constituintes do axé de um altar, posto que o estabelecimento de um templo de candomblé exige que se efetue o que os adoradores chamam de assentamento.

A protoiniciação de Mãe Beata foi sensorial: ela viu, ouviu e sentiu um rito que sua avó realizaria em frente à mala que se tratava da "herança da mãe dela", primeira matriarca a deixar o continente de seus ancestrais. Por isso, ao escrever uma obra intitulada Histórias que a minha avó contava, Mãe Beata revisita parte do patrimônio cultural que herdou e a partir do qual formou sua identidade.

Seguindo o mesmo método narrativo identificado em Caroço de Dendê (2008), os contos de Histórias, mais curtos, tecem tramas acerca de animais, seres divinos, pessoas, objetos sagrados, rituais etc., comunicando ensinamentos e provocando reflexões.

A correlação entre má conduta e desrespeito aos orixás, por exemplo, aparece em "O vendedor de orobô", que descreve seu protagonista como "muito avarento e [que] queria ficar rico rápido". Nesse afã de se enriquecer, ele passa a agir de modo desonesto. Quando engana uma "inocente senhora", entregando-lhe três sementes de orobô e três sementes quaisquer em vez de seis orobôs, ele descobre as consequências de sua avareza. A ialorixá que recebeu as sementes vai, ela mesma, à feira, encontra o vendedor "muito doente dos olhos, quase sem enxergar" e então lhe diz:

- Olha, aquela senhora para quem você vendeu os orobôs falsos na semana passada é filha de Xangô, isso é castigo do rei, você parta um orobô em banda e passe nos olhos, pedindo perdão a ele, pois os orobôs são os olhos de Xangô e é através deles que ele vê todas as nossas ações, as boas e as más, para nos julgar (YEMONJÁ, 2004, p. 17). 
Ao somítico comerciante que recorre à desonestidade a fim de acumular riqueza, o deus da justiça responde com cegueira, reafirmando sua intolerância com mentirosos e criminosos. A divindade, reconhecida como um dos reis da cidade iorubana de Oyo, julgaria com castigo exatamente alguém que comercializa sua semente favorita, o orobô (orógbó). O descuido do vendedor está na sua tentativa de conjugar malfeito com a semente símbolo do deus justo e guerreiro. Tal estado de cegueira somente seria curado por via dos "olhos de Xangô", os orobôs, verdadeiras sentinelas do julgamento divino das ações humanas.

A falta de reverência com o sagrado também está presente na fábula "O canto da cigarra", de acordo com a qual uma venerável árvore não recebe o devido respeito da parte da cigarra. Semelhante à avareza do vendedor de orobô, o orgulho que a cigarra nutre por sua voz impede-a de notar a sacralidade da gameleira, vegetal que incorpora "o espírito das árvores".

No Brasil, essa árvore substitui a árvore africana Iroko, mesmo epíteto do orixá arbóreo aos pés do qual todas as divindades podem ser adoradas. O desequilíbrio provocado pelo canto excessivo da cigarra desperta a reação dos pássaros, peixes e todos os animais, os quais tentam inutilmente convencê-la a interromper seu ruído. Chegando ao limite, a situação leva a gameleira a lançar uma maldição contra o inseto: seu estridente som poderia matá-la.

A sacralização dos animais pode ser verificada também em "O vagalume". O conto retrata Nossa Senhora como perseguida por "inimigos que queriam lhe prender e maltratar". Então, ela, protegendo o menino Jesus em seu ventre, corre, junto com São José, "pelas ruínas de uma cidade", à procura de um abrigo (YEMONJÁ, 2004, p. 22). À noite, eles avistam uma luz piscando, que indica a existência de uma gruta. Ao chegarem lá, eles são ajudados por um vagalume, a quem Nossa Senhora abençoa. Este cenário noturno de fuga da ameaça de prisão e maltrato, passando por lugares inóspitos e se abrigando em uma gruta, com o objetivo de se esconderem de perseguidores, tem semelhança, no contexto brasileiro, com a sofrida jornada de escravizados fugitivos que buscavam refúgio na alta noite. Em meio às trevas noturnas, o vagalume, dotado de "uma linda voz", ilumina os caminhos da sagrada família. A contribuição do inseto com sua luz para manter o equilíbrio da vida pode ter relação com o axé, definido como "a própria outorgada luz de Deus tornada acessível a homens e mulheres" (THOMPSON, 1984, p. 5). 
A bênção de Nossa Senhora ao vagalume, transformando-o em seu candeeiro, conota histórias de origem africana em que deuses concedem poderes a seres da natureza. Além disso, o protagonismo de Nossa Senhora na narrativa engrandece sua correspondência no Brasil com Oxum, a divindade que "representa o feminino passivo, que se deixa ficar quieto, enquanto a vida se faz em suas entranhas" (LIGIÉRO, 2006, p. 94), o que se constata especialmente a partir da associação dessa divindade com Nossa Senhora das Candeias (ou da Candelária).

A paridade entre Nossa Senhora e um orixá das águas também é observável no conto "O caranguejo", cujo enredo se assemelha à história "O caranguejo maldito", presente em Caroço de Dendê (YEMONJÁ, 2008, p. 91), no qual se explica o porquê de as pessoas iniciadas no candomblé não consumirem caranguejo. Devido ao seu desrespeito a Omolu - cujas feridas ele mordeu e despedaçou -, o crustáceo é amaldiçoado por Yemanjá, que não apenas interdita a ingestão de sua carne, mas o condena a andar sempre de lado e de frente para trás.

$\mathrm{O}$ entrecho de "O caranguejo" também se finda com o personagem que nomeia o caso castigado, mas quem o dita é Nossa Senhora. A narradora abre com a pergunta que a trama há de responder: "Vocês sabem por que o caranguejo só anda de lado e para trás?". A resposta começa descrevendo Nossa Senhora "andando pelo mundo" e "sendo perseguida" por "um grupo de soldados querendo pegá-la". Ela, então, se refugiou em um manguezal, disfarçada de pescadora: "colocou o menino Jesus num cesto e começou a pescar caranguejo". Temendo ser fisgado por ela, o caranguejo começou a fazer barulho e a picá-la, com o intento de "chamar a atenção dos soldados, para que eles, vendo a falta de jeito dela, percebessem que não era pescadora e a levassem presa". Seu plano, entretanto, falhou, pois os algozes foram embora, porém Nossa Senhora o indagou:

- Por que você queria me entregar aos soldados?

Ele muito sem graça respondeu:

- Ah! Eu imaginei que a Senhora fosse me pescar.

Ela então disse:

- Olha, eu vou lhe perdoar, mas de hoje em diante você só vai andar de lado e para trás.

Você já reparou como o caranguejo ainda fica assim pelo castigo que recebeu de Nossa Senhora? (YEMONJÁ, 2004, p. 12). 
Assim como em "O vagalume", Nossa Senhora se encontra em uma situação de ameaça bastante semelhante aos escravizados fugitivos: "andando pelo mundo e sendo perseguida" por um grupo de homens armados. Desta vez, entretanto, ela está sozinha, sem a assistência do coadjuvante José para dizer "olha ali uma gruta", como em "O vagalume". A sua bem-sucedida capacidade de distraí-los com disfarce e performance de pescadora em um mangue lembra as possíveis estratégias dos negros que tentavam escapar dos grilhões. A presença do menino Jesus, ademais, realça a imagem materna da protagonista, bem próxima de Iemanjá (mãe dos peixes) e Oxum (protetora da gravidez). O perdão alcançado pelo crustáceo não anula a sua pena: andar de lado e para trás, mesmo decreto da deusa das águas do mar em "O caranguejo maldito".

Iemanjá também se indispõe com outro ser aquático, o peixe aramaçá. A proibição do consumo de sua carne aos filhos do orixá aparece em Caroço de Dendê (YEMONJÁ, 2008, p. 93-94) com consequências para quem viola o preceito. Em "Aramaçam", publicado em Histórias, a autora oferece uma explicação para a quizila.

Iemanjá estava na beira do mar penteando seus lindos cabelos e ajeitando suas vestes de algas verdes e fluorescentes quando olhou para o lado e viu um lindo peixe prateado nadando perto dela, esse peixe se chama aramaçam. Percebendo que a maré estava subindo, ela perguntou ao peixe:

- Aramaçam, aramaçam, a maré enche ou vaza?

O peixe fazendo uma careta muito feia para Iemanjá repetiu a pergunta com a boca torta:

- Aramaçam, aramaçam, a maré enche ou vaza?

Iemanjá vendo seu desdém disse:

- Peixe, você não me conhece. Eu sou dona de tudo isto, e de agora em diante, você vai ficar com a cara torta.

Esse peixe é uma grande quizila dos filhos de Iemanjá, não devendo nunca ser comido por eles (YEMONJÁ, 2004, p. 38).

A indiferença desse peixe diante daquela que governa o mar jamais seria esquecida. A pergunta acerca da maré foi a oportunidade de o peixe definir se a sua sina seria inflamar o orixá ou apaziguá-lo, mas ele escolhe a primeira opção, negando submissão à dona das águas em que vive. Seu desrespeito para com Iemanjá custa-lhe caro. A "careta muito feia" que ele oferta à deusa marcará sua aparência daquele momento em diante. Um contraste estético é estabelecido entre a beleza da divindade com "lindos 
cabelos" e "vestes de algas verdes e fluorescentes" e o aramaçam, que embora fosse "um lindo peixe prateado", passaria a "ficar com a cara torta", gerando asco nos devotos da deidade.

Em outra história que Mãe Beata ouviu de sua avó, ela retrata duas crianças gêmeas que "eram dotadas de grande sabedoria, e tudo que falavam acontecia” (YEMONJÁ, 2004, p. 26). Um dia, o filho primogênito disse à sua mãe que tinha sonhado que ela havia ido mariscar e que encontrava pérolas dentro das ostras que colhia. Em seu sonho, ela vendia as joias, o que faria com que a família deixasse de passar necessidade e ficasse muito rica. Todavia, para que recebessem tal bênção, sua mãe deveria prestar uma oferenda a Janaína e outra a Cosme e Damião.

Apesar de se mostrar cética no início, a mulher foi convencida pelos filhos a fazer as oferendas. Três dias mais tarde, depois de mariscar, ela levou para casa um cesto cheio de ostras. Quando abriu os moluscos, havia uma pérola dentro de cada um deles. Como resultado de tal milagre, ela pôde comprar uma casa, roupas e sapatos para ela e seus filhos e guardar dinheiro para nunca mais passarem fome. A narradora conclui com um ensinamento: "A ostra é um molusco que vive no mar, dentro dela é que são geradas as verdadeiras pérolas" (YEMONJÁ, 2004, p. 26).

Intitulado "Os gêmeos", o relato encena alguns aspectos da tradição iorubá no contexto de uma família pobre brasileira, uma realidade comum a muitos afrodescendentes. A imagem de meninos gêmeos faz referência às divindades gêmeas conhecidas como Ibeji, termo iorubá que denota o nascimento de gêmeos e que emana das palavras ibi (nascimento) e èjì (dois).

Populares no Brasil, São Cosme e Damião foram combinados com essas divinas figuras gêmeas em tradições de origem africana. Além disso, na cultura iorubá, há um ritual complexo para o nascimento de gêmeos; e, se um deles morre, uma figura de madeira é esculpida e guardada pela criança que sobreviveu. Essa ênfase cultural em gêmeos é percebida onde quer que as populações africanas estejam localizadas e é parte de seu legado histórico: “A importância de gêmeos na África e na Diáspora Africana está certamente ligada ao fato de que a taxa de gêmeos registrada na África é mais elevada do que em qualquer outro lugar do mundo" (HOULBERG, 2005, p. 16).

A narrativa de Mãe Beata reconecta símbolos religiosos ao descrever a necessidade de se fazer oferendas aos santos gêmeos e a Janaína, codinome de Iemanjá no Brasil, a fim de superar a pobreza e a fome. 
Filhos de Oxum com Xangô, os Ibejis foram criados por Iemanjá. Das águas dominadas por esse orixá materno, virá o tesouro por intermédio do qual os membros dessa família carente renovarão suas vidas. Em que pese a descrença da pescadora nos orixás ("A mulher que não acreditava em nada, foi logo desdenhando"), ela reconsidera sua postura a partir da insistência dos seus gêmeos, emblemas de Ibeji, representantes do "nascimento de uma nova vida interior" (LIGIÉRO, 2006, p. 105).

As águas como repositório de tesouros tematizam o conto " $\mathrm{A}$ fortuna que veio do mar", de Caroço de Dendê, o qual também destrinça a mudança da sorte de personagens pobres. Enquanto quem abre os olhos do pescador filho de Omolu (outro orixá acolhido por Iemanjá) é um oluô (senhor dos mistérios), a pescadora de ostras tem sua cegueira escamada pela visão única que um dos gêmeos obtém em sonho. Seja da barriga de um grande peixe, seja de dentro de ostras, o desfecho de ambas as histórias é semelhante: os pobres pescadores pescam as joias que a rainha do mar lhes concede, alcançando a prosperidade que porá fim ao seu sofrimento.

Em "A fortuna que veio do mar", o foco está em um homem "muito bom, mas muito pobre", que era humilhado por seus irmãos em razão de sua condição social. Ijiberu, filho de Omolu, chegou a pensar em abandonar a pescaria, mas a mulher o aconselhou a consultar "um oluô muito acreditado, chamado Tio Joaquim". Devoto dos orixás, ele se dirige à casa do ancião.

Tio Joaquim pegou o opelé, jogou e disse:

- Olha, a resposta eu já sabia, mas aqui diz pra dizer pra você que está perto de você ficar rico. Sua fortuna vem do mar, trazida por um peixe. Não diga nada a ninguém.

O homem foi para casa e contou para a mulher o que o oluô falou, e pediu segredo (YEMONJÁ, 2008, p. 71-72).

No mar, estão a pobreza e a fortuna daquele que "tinha muita fé com os orixás". A humilhação sofrida por Ijiberu não seria eterna, pois ele é filho de Omolu, o médico dos pobres. Quem revela a sua boa sorte é o oluô (olúwo), sacerdote da prática de consulta divinatória conhecida como ifá. Como senhor (olú) dos mistérios e segredos (awo), Tio Joaquim já sabia da resposta antes de efetuar a adivinhação através do opelé (òpèlè: corrente intercalada com oito sementes côncavas usada nas leituras oraculares). Ao desvelar o segredo de que Ijiberu ficaria rico, o oluô 
pede para ele não dizer nada a ninguém. No entanto, ele conta o que ouviu à mulher, que relata o ocorrido para a concunhada, espalhando a notícia para os outros irmãos. O resultado é mais zombaria, marca de seu sofrimento. Confirmada a predição de que um peixe traria sua fortuna, Ijiberu se enriquece e deixa de ser humilhado pelos irmãos, donde o realce da autora para a moral da história: "Não se deve zombar [da pobreza] dos outros" (YEMONJÁ, 2008, p. 72).

Se a riqueza tem sua origem divina, o mesmo se pode dizer da miséria. Em Caroço de Dendê, no conto "O Odu Ojonilé" (YEMONJÁ, 2008, p. 111-112), os odus Ojonilé e Ossá dirigem sua reclamação a Orumilá por serem acusados pelas pessoas de levarem infortúnios a elas, o que eles julgam como improcedente, pois consideram que os problemas humanos encontram raízes em estilos de vida desregrados. Entretanto, "A praga de Ojonilé contra Obará", um dos contos de Histórias, volta a estabelecer uma correspondência entre Ojonilé e situações adversas.

Entre os Odus, Obará era o maior possuidor de bens, isso fazia com que não se misturasse com os outros, Ojonilé muito se incomodava com a atitude dele, pois, apesar de ser muito trabalhador, e muito honesto, sempre que conseguia ganhar dinheiro alguém em sua família adoecia e lá se iam todas as suas economias. Sempre que isso acontecia, ele logo se lembrava de Obará, para quem tudo vinha fácil, sem que ele fizesse nenhum esforço.

Um dia, Ojonilé, conversando com os outros Odus decidiu que faria alguma coisa para mostrar a Obará que dinheiro não traz felicidade, foi então até a casa da Doença e disse:

- Olha Doença, Obará tem três filhas, Saúde, Vida e Felicidade, eu vou te dar um presente para que algo aconteça a Felicidade.

A Doença pensou e disse:

- Tome aqui essa cabaça, nela você tem tudo que precisa para provocar uma mazela em Felicidade que vai fazer Obará sofrer muito.

Ojonilé fez o que era necessário.

Logo Felicidade começou a entristecer e a definhar, e Obará finalmente entendeu que todo seu dinheiro não servia de nada diante da doença da filha.

Até hoje existe essa demanda entre os dois Odus. Obará dando a riqueza e Ojonilé quase sempre trazendo a doença.

Quem carrega esse Odu deve ter muito cuidado (YEMONJÁ, 2004, p. 31).

O relato dramatiza dois integrantes do conjunto de signos do sistema divinatório conhecido como Ifá. Nessa alegoria dos oráculos, os odus 
se desdobram em qualidades antípodas: Ojonilé está envolto de desdita, ao passo que Obará desfruta de muito êxito. Sendo representantes de destinos, tudo o que podem fazer é negociar entre si. Assim o faz Ojonilé ao ir ao encontro da Doença com o desígnio de dar uma lição a Obará: "dinheiro não traz felicidade". Na cabaça entregue pela Doença, há o necessário para enfermar uma das filhas de Obará, Felicidade.

Ainda que nada tivesse ocorrido às duas outras filhas, Saúde e Vida, o afortunado odu enfim percebe que sua riqueza é inútil frente ao sofrimento da filha adoentada. Já Ojonilé se mantém o mesmo: "quase sempre trazendo a doença", até quando se propõe a corrigir um comportamento. Se aqui ele é bem-sucedido em seu plano por causa dessa sua característica; em "O Odu Ojonilé", esta é justamente a razão por que ele depende da ajuda de outro ser divino para voltar a ser respeitado.

O paralelo entre contos das duas coletâneas de Mãe Beata se nota também em "Saci Pererê e o lenhador", que reverbera os enredos de "O menino que tinha muito saber" e "O colhedor de folhas", de Caroço de Dendê.

O papel de Saci Pererê como guardião das florestas, que pune os destruidores da natureza, remete a Aroni, espírito que habita as matas e possui uma perna, um braço, um olho e apenas metade dos órgãos do corpo. Sua ligação com o culto a Ossâim, o orixá das folhas selvagens, o faz também conhecedor das plantas medicinais, podendo Aroni ser uma versão fon do nome de Ossâim.

No conto, Mãe Beata imprime Aroni-Ossâim na palimpséstica figura da cultura popular. À semelhança de uma divindade iorubá, Saci Pererê se irrita com a atitude de desrespeito do maldoso lenhador, para com seu território sagrado, e decide corrigir tal conduta, com o propósito de lhe "dar um ensinamento". A punição estimula o temor, princípio fundamental na religião dos orixás para que o ofensor se disponha a apaziguar a divindade que insultou. No caso do lenhador atemorizado pelo assobio do Saci, bastou a interrupção de sua atividade predatória para que o equilíbrio fiador da sobrevivência de todos os vegetais voltasse a ser estabelecido.

A obliteração de recursos naturais que advém do "progresso" ameaça a existência das tradições de origem africana. Este é o tema de "A lagoa encantada", um conto ambientado em Cachoeira, município dentro do qual está situado o vilarejo de Santiago do Iguape, terra natal de Mãe Beata.

Conquanto os iorubás sejam uma das mais urbanas das civilizações tradicionais da África negra, seu urbanismo preserva reverência e zelo 
para com a natureza. Herdeiras dessa tradição são as formas religiosas afro-brasileiras denominadas candomblés. Uma de suas expressões aparece nessa historieta como "um candomblé antigo", conhecido como "Candomblé das Velhas". Por ser vetusto, esse local de culto provavelmente representa gerações praticantes de ritos ensinados por suas antepassadas, haja vista a identificação do terreiro com as Velhas, referências matriarcais de manutenção e transmissão de sabedoria.

A localização do templo ao lado de uma lagoa facilita a morada de Oxumarê, o orixá que trabalha para "garantir a perpetuação do ciclo das águas no planeta” (LIGIÉRO, 2006, p. 78). Conhecida como "Cobra Cauã", a divindade africana é tratada como "um encostado", o que se aproxima de uma variante religiosa mais heterogênea (como o candomblé de caboclo), corroborada pelo uso do termo de origem tupi Cauã (gavião), bem como pela atribuição do adjetivo "encantada" à lagoa. Essa cobra se manifesta no corpo de uma pessoa, enroscando-se nela e arrastando-a, uma performance que apresenta uma força tão expressiva quanto a do orixá serpente arco-íris, segundo a narradora. Essa apreciação expõe sua tolerância com a pluralidade das tradições afro-brasileiras, inclusive as que se conjugam de bom grado com elementos não africanos.

Por fim, a extinção desse terreiro está ligada a uma espécie de desenvolvimento da região que provoca a destruição da lagoa. Apesar de perdas históricas como essa, conclui-se que "a força e a fé do povo negro não se acaba", uma afirmação que eleva a narrativa ao plano político e ético em que se dá a formação da identidade afrodescendente.

A subsistência dos africanos, após a escravidão ter sido abolida no Brasil, surge em "A folha de ingá". Entre as muitas estratégias que os escravizados utilizavam para sobreviverem após o fim do sistema escravocrata, constava o domínio da magia: "Para os negros africanos, que sempre eram grandes conhecedores de magia, a folha do ingá tinha muito valor, pois eles conseguiam transformá-la em dinheiro" (YEMONJÁ, 2004, p. 34).

A condição social desonrante dos negros após a abolição da escravatura se torna evidente na sua falta de recursos para comprar alimentos, cuja venda estava sob o controle daqueles que outrora os escravizavam. $\mathrm{O}$ estratagema de transformar folhas de ingá em dinheiro possibilita a aquisição dos seus mantimentos. Trata-se de uma ação coletiva com a participação de outras mãos, incluindo aquelas dos mais jovens que efetivam a compra, a fim de burlar a desconfiança dos comerciantes. A história canoniza, portanto, a folha de uma árvore nativa do Novo Mundo, tornando-a 
significativa para a história diaspórica dos africanos. O responsável por arquitetar a façanha de transformar a folha em dinheiro é Tio Joaquim, conhecido por seu temível poder mágico. Em Caroço de Dendê, esse personagem age como um mestre dos segredos divinatórios (oluô).

Enquanto essa narrativa anteriormente tateia as adversidades que os negros no contexto pós-abolicionista enfrentavam para satisfazerem suas necessidades mais elementares, o último conto de Histórias descortina parte do dia a dia dos africanos durante a escravidão, ajustando o seu foco para as experiências de um casal.

Pai Tonho vivia em um engenho, ele era um escravo reprodutor, aquele que era preparado pelos senhores para dormir com várias escravas e dar muitas crias; quanto mais filhos homens ele fazia, mais regalias tinha com os senhores: ele comia carne de baleia com copioba, que é a farinha de mesa mais fina, e só bebia leite com nata, enquanto os outros escravos tomavam o soro do leite, que é o que sobra depois de tirados todos os nutrientes (YEMONJÁ, 2004, p. 46-47).

Diante de tantas histórias não contadas dos sujeitos escravizados, Mãe Beata realiza um estudo de caso. A figura de um escravizado reprodutor ecoa a história da própria autora, cujo bisavô ocupava a mesma posição no engenho em que vivia com sua esposa: "ele dormia três dias da semana com minha bisavó e outros três com as escravas da casa. Domingo era o dia de folga, com certeza. A sinhá teve um grande lucro com meu bisavô, [pois] fazia grandes vendas para a redondeza" (citado por COSTA, 2010, p. 31). O conto informa que, nessas condições, "lucro" equivale a produzir filhos homens, uma conquista genética vista como responsabilidade apenas do homem, o que justifica seus privilégios nutritivos.

O nome do protagonista marca sua identidade nos tempos coloniais, associando-a com sua função social: Pai Tonho tinha muitos filhos porque era um escravizado reprodutor, e vice-versa. O que gera o conflito do drama é o relacionamento entre as "duas paixões" desse homem: sua mulher Rita e o seu galo Bonito. Assim como a bisavó de Mãe Beata, Rita era uma "mucama", ou "escrava de dentro", função que se diferenciava por envolver afazeres domésticos, passeios com a sinhá, bem como cuidado e amamentação dos filhos de seus senhores. A "linda escrava" rivaliza com o galo que Pai Tonho "criava desde pintinho" e que era "filho da galinha mãe do terreiro", simbolizando, assim, o único filho que esse pai de muitos poderia ter por perto. 
Impedida de dormir pelo canto da ave toda madrugada, a mulher passa a culpar o galo por ter que acordar cedo para satisfazer o desejo sexual do marido. Seu plano de dar cabo de Bonito por meio da mentira de que estaria grávida fracassa, pois o bicho havia sido dedicado a Exu. Logo, o galo haveria de morrer pelas mãos de seu dono: em cima de um pé de ekika (um tipo de fruta ácida), a ave cacareja pela última vez e cai morta. Um barulho e um cheiro de cachaça e enxofre no ar atestam a presença do orixá que buscou o que era dele.

Ao tomar consciência disso, Rita se arrepende, pede perdão e conta a verdade acerca de sua intenção de enganar Pai Tonho. Conjugada com a mentira, que "tem perna curta", a ignorância quanto aos deuses pode resultar em perdas. O jogo performático de dissimulação humana pode ser interrompido a qualquer hora por uma abrupta entrada em cena de uma poderosa divindade.

\section{Considerações finais}

A religião afro-brasileira contribuiu para a formação da identidade de Mãe Beata, a quem fora negada a possibilidade de se identificar com um nome africano até o momento em que fora iniciada no candomblé.

Apesar das adversidades, a autora percorre o caminho da afirmação de suas raízes. Por meio do candomblé, ela recupera elementos que se tornaram significativos no processo de descoberta de sua "verdadeira identidade". Revela-se, pois, o rizoma de sua luta como filha de uma tradição ancestral iorubá, constituída na diáspora do Novo Mundo, isto é, repercutindo heranças e criando novas formas.

Para Paul Gilroy, as formas culturais produzidas por sujeitos negros diaspóricos são "estereofônicas, bilíngues, ou bifocais" (GILROY, 1993, p. 3), constituindo um "mundo atlântico negro". A fusão de tradições africanas com novos elementos nas Américas produziu formas culturais que fariam surgir no mundo atlântico um verdadeiro mundo atlântico negro. Desse novo mundo, surge o candomblé, uma religião diaspórica para cuja formação contribui o entrecruzamento de tradições africanas. Trata-se de uma "religião atlântica negra" (Black Atlantic religion), como bem percebeu J. Lorand Matory (2005).

Uma vez que "[a] cultura negra é o lugar das encruzilhadas" (MARTINS, 2010, p. 64), quem se encontra nesses espaços de cruzamento são sujeitos negros com histórias de vida que, apesar de ligadas aos seus antepassados africanos, constroem-se em vários lugares. 
Ao se dirigir a pessoas que considera guardiãs de sabedoria ancestral e ritos de origem africana no Brasil, Mãe Beata reafirma a necessidade de solidariedade, amor, fé e respeito, a fim de que se criem políticas públicas que protejam as tradições religiosas afro-brasileiras. Reivindicando "apoderamento" e "meios para cuidar do que nos restou", a autora reconhece que os tempos de "chibata" e "correntes" já passaram, "pois aquela coisa que negro só sabia semear e não colher acabou, nós estamos semeando tanto culturalmente quanto espiritualmente e socialmente" (citado por COSTA, 2010, p. 131).

Preocupada com a sobrevivência de sua herança cultural, a autora não apenas clama pela observância das leis que garantem a proteção dos cultos afros, mas também se alarma com a urgência em transmitir seu "saber ancestral" às novas gerações, o que traduz como "tirar algo do [seu] baú de memória" para compartilhar com os mais jovens. Em outro momento, Mãe Beata menciona uma "nascente" que se mantém viva em virtude de várias frentes defensoras de uma humanidade igualitária:

As ações e o saber ancestral dos terreiros e suas mulheres ainda não foram de todo esgotados, pois essa nascente jamais secará. Enquanto houver livros, fóruns e pessoas com tais iniciativas, continuaremos vivas, lutando e guerreando não só por nós, mulheres negras e guerreiras, mas também pela sociedade mais ampla, que muito ganhará com tais reflexões e ações. Gotas de água juntas se transformam em chuva (citado por COSTA, 2010, p. 18).

Com isso, ativismo e ancestralidade se casam no discurso da autora. A sensibilidade ao cotidiano de homens e mulheres afrodescendentes, cujas vidas foram destinadas ao esquecimento por força da escravidão, corresponde à singeleza da descrição do processo de reminiscência de um passado ancestral. Como já afirmou a crítica tobaguiana Carole Boyce Davies, "negar as vozes das mulheres negras produz aquela memória e estresse emocionais, que podem implodir ou sair de forma explosiva" (DAVIES, 1995, p. 3). Na linha de frente literária, Mãe Beata de Yemonjá produziu literatura como participante de seu contexto, reverberando e recriando saberes ancestrais para que a história da África no Brasil pudesse sempre ser recontada pelas vozes de seus descendentes. 


\section{REFERÊNCIAS}

AFOLABI, Niyi. Afro-Brazilians: cultural production in a racial democracy. Rochester: University of Rochester Press, 2009.

COSTA, Haroldo. Mãe Beata de Yemonjá: guia, cidadã, guerreira. Rio de Janeiro: Garamond; Fundação Biblioteca Nacional, 2010.

DAVIES, Carole Boyce. Hearing black women's voices: transgressing imposed boundaries. In: DAVIES, Carole Boyce ; OGUNDIPE-LESLIE, 'Molara (Ed.). International dimensions of black women's writing. Londres: Pluto Press, 1995, p. 3-14.

GATES, Jr., Henry Louis. The signifying monkey: a theory of African-American literary criticism. Nova Iorque: Oxford, 1989.

GILROY, Paul. The Black Atlantic: modernity and double consciousness. Cambridge: Harvard University Press, 1993.

HOULBERG, Marilyn. Magique Marasa: the ritual cosmos of the twins and other sacred children. In: BELLEGARDE-SMITH, Patrick (ed.). Fragments of Bone: neo-african religions in a new world. Urbana and Chicago: University of Illinois Press, 2005, p. 13-31.

LIGIÉRO, Zeca. Corpo a corpo: estudo das performances brasileiras. Rio de Janeiro: Garamond, 2011.

MARTINS, Leda Maria. A oralitura da memória. In: FONSECA, Maria Nazareth Soares (Org.). Brasil afro-brasileiro. 3. ed. Belo Horizonte: Autêntica, 2010. p. 60-86.

MATORY, J. Lorand. Black Atlantic religion: tradition, transnationalism, and matriarchy in the Afro-Brazilian Candomblé. Princeton: Princeton University Press, 2005.

MBEMBE, Achille. Crítica da razão negra. Trad. Marta Lança. 2a. ed. Lisboa: Antígona, 2017.

MCLAUGHLIN, Andrée Nicola. A renaissance of the spirit: black women remaking the universe. In: BRAXTON, Joanne M. \& MCLAUGHLIN, Andrée Nicola (eds.). Wild women in the whirlwind: Afra-American culture and the contemporary literary renaissance. New Brunswick: Rutgers, 1990, p. xxxi-xlix.

SAID, Edward W. Cultura e imperialismo. Trad. D. Bottman. São Paulo: Companhia das Letras, 1995.

THOMPSON, Robert Farris. Flash of the Spirit: African \& Afro-American Art \& Philosophy. Nova York: Random House, 1984. 
YEMONJÁ, Mãe Beata de. Caroço de dendê: a sabedoria dos terreiros: como ialorixás e babalorixás passam seus conhecimentos a seus filhos. 2a. ed. Rio de Janeiro: Pallas, 2008.

Histórias que a minha avó contava. São Paulo: Terceira Margem, 2004.

Recebido em: 07/05/2019

Aceito em: 30/09/2019 